\title{
Characterization, Density and In Vitro Controlled Release Properties of Mimosa (Acacia mearnsii) Tannin Encapsulated in Palm and Sunflower Oils
}

\author{
Shehu Lurwanu Ibrahim and Abubeker Hassen *D \\ Department of Animal Science, University of Pretoria, Private Bag X20, Hatfield 0028, South Africa; \\ abumubarak480@gmail.com \\ * Correspondence: Abubeker.hassen@up.ac.za
}

check for updates

Citation: Ibrahim, S.L.; Hassen, A. Characterization, Density and In Vitro Controlled Release Properties of Mimosa (Acacia mearnsii) Tannin Encapsulated in Palm and Sunflower Oils. Animals 2021, 11, 2919. https:// doi.org/10.3390/ani11102919

Academic Editor: Gonzalo Hervás

Received: 25 August 2021

Accepted: 6 October 2021

Published: 9 October 2021

Publisher's Note: MDPI stays neutral with regard to jurisdictional claims in published maps and institutional affiliations.

Copyright: (c) 2021 by the authors. Licensee MDPI, Basel, Switzerland. This article is an open access article distributed under the terms and conditions of the Creative Commons Attribution (CC BY) license (https:// creativecommons.org/licenses/by/ $4.0 /)$.
Simple Summary: The utilization of tannin in mitigating enteric methane suffers a setback in terms of dietary intake and digestibility because of the tannin's astringency and instability in the gastrointestinal tract. Microencapsulation of tannin using lipids could mask its bitter taste and ensure its controlled release at the target site. This study aimed to encapsulate Acacia mearnsii tannin extract with palm and sunflower oils, and to evaluate the efficacy of the encapsulated tannins with regards to encapsulation efficiency, density, and release of tannin in media, simulating the rumen, abomasum and the small intestine. Mimosa tannin was encapsulated in palm oil or sunflower oil using a double emulsion method. The findings showed that encapsulated mimosa tannins in the palm oil and sunflower oil had high encapsulation efficiencies with smaller sizes and were lower in density compared to the unencapsulated mimosa tannin. The amount of tannins released by the unencapsulated tannin after $24 \mathrm{~h}$ in rumen (94\%), abomasum (92\%) and small intestine (96\%) simulated buffers, were reduced to $24 \%, 21 \%$ and $19 \%$, respectively, for the sunflower oil microparticle and $18 \%, 20 \%$ and $16 \%$, respectively, for the palm oil microparticle in the same buffers and periods. Palm oil and sunflower oil successfully encapsulated the mimosa tannin and controlled its release in the gastrointestinal tract simulated media without compromising rumen fermentation.

Abstract: Tannin has gained wider acceptance as a dietary supplement in contemporary animal nutrition investigations because of its potential to reduce enteric methane emission. However, a major drawback to dietary tannin intake is the bitter taste and instability in the gastrointestinal tract (GIT). The utilization of fats as coating materials will ensure appropriate masking of the tannin's aversive taste and its delivery to the target site. The aims of this study were to encapsulate mimosa tannin with palm oil or sunflower oil, and to assess the microcapsules in terms of encapsulation efficiency, morphology, density, and in vitro release of tannin in media simulating the rumen ( $\mathrm{pH}$ 5.6), abomasum ( $\mathrm{pH}$ 2.9) and small intestine ( $\mathrm{pH}$ 7.4). The microencapsulation of mimosa tannin in palm or sunflower oils was accomplished using a double emulsion technique. The results revealed that encapsulated mimosa tannins in palm oil $\left(\mathrm{EMT}^{\mathrm{P}}\right)$ and sunflower oil $\left(\mathrm{EMT}^{\mathrm{S}}\right)$ had high yields $(59 \%$ vs. $58 \%)$ and encapsulation efficiencies ( $70 \%$ vs. $68 \%$ ), respectively. Compared to unencapsulated mimosa tannin (UMT), the morphology showed that the encapsulated tannins were smaller in size and spherical in shape. The UMT had $(p<0.01)$ higher particle density $\left(1.44 \mathrm{~g} / \mathrm{cm}^{3}\right)$ compared to $1.22 \mathrm{~g} / \mathrm{cm}^{3}$ and $1.21 \mathrm{~g} / \mathrm{cm}^{3}$ for the $\mathrm{EMT}^{S}$ and $\mathrm{EMT}^{\mathrm{P}}$, respectively. The proportion of tannins released by the UMT after $24 \mathrm{~h}$ in the rumen (94\%), abomasum (92\%) and small intestine (96\%) simulated buffers, reduced $(p<0.01)$ to $24 \%, 21 \%$ and $19 \%$ for the $\mathrm{EMT}^{\mathrm{S}}$ and $18 \%, 20 \%$ and $16 \%$ for the $\mathrm{EMT}^{\mathrm{P}}$ in similar media and timeframe. The release kinetics for the encapsulated tannins was slow and steady, thus, best fitted by the Higuchi model while the UMT dissolved quickly, hence, only fitted to a First order model. Sequential tannin release also indicated that the $\mathrm{EMT}^{\mathrm{S}}$ and $\mathrm{EMT}^{\mathrm{P}}$ were stable across the GIT. It was concluded that the microencapsulation of mimosa tannin in palm or sunflower oils stabilized tannins release in the GIT simulated buffers with the potential to modify rumen fermentation. Further studies should be conducted on the palm and sunflower oils microcapsules' lipid stability, fatty acid transfer rate in the GIT and antioxidant properties of the encapsulated tannins. 
Keywords: particle density; gastrointestinal tract; microencapsulation; mimosa tannin; morphology; palm oil; sunflower oil; release kinetics

\section{Introduction}

The utilization of tannins as feed supplements in recent ruminant nutrition studies is linked to their positive roles in modulating rumen fermentation, methane $\left(\mathrm{CH}_{4}\right)$ emission and protein metabolism [1]. Enteric $\mathrm{CH}_{4}$ is one of the by-products of anaerobic fermentation of structural carbohydrates in the rumen which has a potential global warming impact twenty-five times greater than that of carbon dioxide [2]. Several studies have showed that condensed tannins are capable of mitigating $\mathrm{CH}_{4}$ emissions either directly by interfering with the proliferation and activities of methanogens or indirectly through the reduction in fiber degradation and hindrance of protozoa activities [3-5]. In addition, condensed tannins have the ability to bind dietary proteins at the normal rumen $\mathrm{pH}$, thereby increasing amino acid absorption in the small intestine [6,7].

Among the condensed tannins of the rich leguminous trees mostly consumed by ruminants in the tropics [8], Acacia mearnsii, popularly known as mimosa tannin [9], is considered as the most widely spread and highly invasive alien species in South Africa, covering an area of over 2.5 million hectares [10], and more than 130,000 ha of commercial plantations [11]. Numerous studies have revealed that Mimosa tannin has the potential to reduce enteric $\mathrm{CH}_{4}$ and ammonia nitrogen $\left(\mathrm{NH}_{4}-\mathrm{N}\right)$ production while enhancing dietary protein by-pass. For instance, when an extract of mimosa tannin was fed to cows, $\mathrm{CH}_{4}$ and urine nitrogen were reduced by up to $29 \%$ and $9.3 \%$, respectively [12]. Likewise, in sheep, urine nitrogen dropped by $59 \%$ and $\mathrm{CH} 4$ by $13 \%$ [13]. Additionally, A. mearnsii tannins increased propionate levels beyond $100 \mathrm{~g} / \mathrm{kg}$ of dry matter (DM) against the acetate [14].

However, the oral administration of tannins suffers some drawbacks in terms of dietary intake and digestibility, due to the bitter taste largely attributed to the tannins' negative reaction with salivary proteins [15], as well as their instability and binding nature in the gastrointestinal tract (GIT) [16]. Furthermore, intake and digestibility of the tannins have been found to reduce when condensed tannins are fed above $50 \mathrm{~g} / \mathrm{kg}$ of DM [17,18]. Some studies such as that of Priolo et al. [19], reported a 48 g reduction in average daily gain in sheep while Bhatta et al. [20] observed a decrease of 30\% in nitrogen retention and an increase in energy loss up to $45 \%$ in goats supplemented with high amounts of condensed tannins. In addition, Grainger et al. [12] recorded a $29.7 \%$ reduction in milk yield when a large quantity of mimosa tannin extract was fed to cows. Therefore, there is a need for the development of a technique that will ensure the appropriate masking of tannins' aversive taste and their sustained release into the GIT without compromising normal rumen function.

Various encapsulation technologies have been developed by feed and pharmaceutical industries to conceal the aversive tastes of many bioactive compounds, to improve their stability and control their release to target site of digestion without any adverse effects [21,22]. Bakry et al. [23] defined encapsulation as a method of building an efficient barrier between the active ingredients and coating material to prevent any form of chemical and physical reactions, and to sustain the biological, functional, and physicochemical characteristics of the active ingredient. Numerous microencapsulation methods were adopted such as spray-drying, spray-cooling, spray-chilling, freeze-drying, centrifugal suspension separation, inclusion complexation and coacervation using various wall materials [24]. The best coating material for use in masking the bitter taste of tannins should be inexpensive, tasteless, have low viscosity, be a good film former, have good emulsifying properties and be able to safeguard the bioactive compound up to the target site $[25,26]$.

However, the feed industry is faced with the challenges of selecting appropriate wall materials that are available, inexpensive, and safe [27], which affect the practicability of encapsulation technology in animal nutrition. In southern Africa, sunflower oil and 
palm oil are found in abundance and could serve as suitable wall materials for tannin encapsulation due to their desirable aroma [23], good emulsifying properties and low viscosity [28]. A review by Eckard et al. [29] reported a significant reduction in $\mathrm{CH}_{4}$ when sunflower oil was supplemented in the diets of ruminants. In addition, in vitro $\mathrm{CH}_{4}$ volume dropped when palm oil was adopted as a coating material to encapsulate $A$. mearnsii extract using a solid-in-oil-water $(\mathrm{S} / \mathrm{O} / \mathrm{W})$ technique [30]. However, literature on using lipids such as sunflower and palm oils as coating materials to mask the tannins' bitter taste and ensure their controlled release to the target sites of function in the GIT is still scarce. The objectives of the present study, therefore, are to encapsulate mimosa tannin with sunflower and palm oils using the double emulsion method, and to evaluate the sunflower and palm oils' microparticles in terms of their encapsulation efficiency, morphology, density, and in vitro release rate in various media simulating the GIT.

\section{Materials and Methods}

\subsection{Study Area}

The experiment was conducted in the Department of Animal Sciences, University of Pretoria, South Africa. The location lies at a latitude $25^{\circ} 44^{\prime} 30^{\prime \prime}$ south and longitude $28^{\circ} 15^{\prime} 30^{\prime \prime}$ east at an altitude of $1360 \mathrm{~m}$ above sea level [31]. This research was approved by the Animal Ethics Committee of the University of Pretoria (Ref No: EC075-17).

\subsection{Materials}

The mimosa (Acacia mearnsii) tannin extract used in this study was gifted by the UCL company Pty (Ltd), Dalton, South Africa. The extract was reported to have been obtained from the bark of the A. mearnsii tree following hot water extraction processes at specific temperature, pressure, and time. The water was removed using a vacuum evaporator and the extract was air-dried into fine powder, packaged, and refrigerated before use [32]. The palm and sunflower oils were purchased from Pick ' $n$ ' Pay grocery, Hatfield, Pretoria. The emulsifiers (Span80, Tween80) and dichloromethane (DCM) were procured from Sigma-Aldrich, St. Louis, MO, USA. Filter bags (F57 fiber) were purchased from ANKOM Technology, New York, NY, USA. All other reagents utilized were of analytical grade and sourced from Sigma-Aldrich, Johannesburg, South Africa.

\subsection{Characterization of Mimosa Tannin}

Mimosa tannin powder $(0.2 \mathrm{~g})$ was added in $25 \mathrm{~mL}$ volume glass beakers containing aqueous acetone $(10 \mathrm{~mL})$ and dissolved for $20 \mathrm{~min}$ in an ultrasonic bath. The solution was transferred into tubes and centrifuged in a refrigerated centrifuge at $2500 \mathrm{rpm}$ for $15 \mathrm{~min}$. and the supernatant collected and kept in ice blocks. The concentrations of total phenol, non-tannin phenols and total tannins in the extracts were determined using the Folin-Ciocalteu method [33], as a tannic acid equivalent, while condensed tannin content was analyzed as a leucocyanidin equivalent using the Butanol- $\mathrm{HCl}$ method [34]. The proportion of hydrolysable tannin was estimated by the differences between the total tannins and condensed tannins [35].

\subsection{Microencapsulation of Mimosa Tannin}

Mimosa tannin was encapsulated with either palm oil or sunflower oil using the $\mathrm{S} / \mathrm{O} / \mathrm{W}$ technique described by Adejoro et al. [30] with little modification. The water (W) solution was first prepared in a $500 \mathrm{~mL}$ beaker by adding $300 \mathrm{~mL}$ distilled water comprising $1 \%(w / v)$ Tween 80 emulsifier. The mixture was then homogenized using an iron rod homogenizer (PRO400DS, Pro Scientific Inc., Oxford, CT 06478, USA) set at 20,000 revolutions per minute (rpm) for 3 min until the solution foamed. The solid-in-oil $(\mathrm{S} / \mathrm{O})$ solution was simultaneously prepared by adding $8.5 \mathrm{~g}$ of mimosa tannin powder into a $100 \mathrm{~mL}$ beaker containing $30 \mathrm{~mL}$ palm or sunflower oil solution in DCM $(50 \mathrm{mg} / \mathrm{mL})$ mixed with $0.5 \%(w / v)$ Span 80 as a surfactant then stirred thoroughly for 2 min using a magnetic stirrer set at $400 \mathrm{rpm}$. The $\mathrm{S} / \mathrm{O}$ solution was subsequently added to the $\mathrm{W}$ 
solution and homogenized for $3 \mathrm{~min}$ at 20,000 rpm to form the final S/O/W mixture. The mixture was stirred for three hours using a magnetic stirring plate set at $800 \mathrm{rpm}$ to completely evaporate the DCM. The palm and sunflower oil microcapsules produced were squeezed through a four-fold layer of cleaned cheese cloth, rinsed with about $100 \mathrm{~mL}$ distilled water, transferred into the aluminum container, and freeze-dried for 5 days. The encapsulated mimosa tannins in palm oil $\left(\mathrm{EMT}^{\mathrm{P}}\right)$ or sunflower oil $\left(\mathrm{EMT}^{\mathrm{S}}\right)$ were collected, ground to powder and refrigerated before analysis.

\subsection{Optimization of Mimosa Tannin Microcapsules}

\subsubsection{Encapsulation Efficiency and Tannin Yield}

The encapsulation efficiency (Ee) and tannin yield of sunflower and palm oil microcapsules were determined according to the procedure of Adejoro et al. [30], with slight changes. The powdered samples $(0.1 \mathrm{~g})$ of $\mathrm{EMT}^{\mathrm{P}}$ and $\mathrm{EMT}^{\mathrm{S}}$ were separately weighed into a beaker containing DCM $(20 \mathrm{~mL})$, and heated in an ultrasonic bath for $10 \mathrm{~min}$ to disband the lipid coatings. The solutions were centrifuged at $2500 \mathrm{rpm}$ for $10 \mathrm{~min}$ and the tannin pellets were collected and dissolved in $70 \%$ aqueous acetone $(20 \mathrm{~mL})$ to reconstitute the extracts. The concentration of the actual loaded tannin $\left(\mathrm{LT}_{\mathrm{a}}\right)$ was determined using a spectrophotometer absorbance at $725 \mathrm{~nm}$. The Ee of the $\mathrm{EMT}^{\mathrm{P}}$ and $\mathrm{EMT}^{\mathrm{S}}$ were estimated from the Equation (1) below:

$$
\mathrm{Ee}(\%)=\frac{\mathrm{LT}_{\mathrm{a}}}{\mathrm{LT}_{\mathrm{t}}} \times 100
$$

where Ee = encapsulation efficiency, $\mathrm{LT}_{\mathrm{a}}=$ actual loaded tannin $(\%, w / w)$ in the oil microcapsules and $\mathrm{LT}_{\mathrm{t}}=$ theoretical loaded tannin (i.e., the amount of mimosa tannin added during encapsulation).

The mimosa tannin encapsulation yield (\%) was estimated from the total tannin content obtained in the EMT ${ }^{\mathrm{P}}$ and $\mathrm{EMT}^{\mathrm{S}}$ microcapsules and the total amount of tannin initially added as shown in Equation (2):

$$
\text { Yield }(\%)=\frac{\text { amount of tannin obtained }(\mathrm{g})}{\text { total tannin added }(\mathrm{g})} \times 100
$$

\subsubsection{Scanning Electron Microscopy}

The morphology of the $\mathrm{EMT}^{\mathrm{P}}$ and $\mathrm{EMT}^{\mathrm{S}}$ compared to the unencapsulated mimosa tannin (UMT) were determined using a scanning electron microscope (SEM) following the procedure of Taylor et al. [36] with slight modifications. The powdered samples (UMT, $\mathrm{EMT}^{\mathrm{P}}$ and $\mathrm{EMT}^{\mathrm{S}}$ ) were prepared separately and smeared with carbon, then mounted to the stubs of the SEM (JEOL, JSM-840 Tokyo, Japan) using adhesive tape and viewed at $20 \mathrm{kV}$.

\subsubsection{Microparticle Density}

The three mimosa tannin samples (UMT, $\mathrm{EMT}^{\mathrm{P}}$ and $\mathrm{EMT}^{\mathrm{S}}$ ) were evaluated for particle density using a Gas Pycnometer (AccuPyc II 1340 Micromeritics Instr. Corp. Norcross, GA, USA). The powdered samples (52 g) were separately transferred and sealed into the vessel of the Pycnometer. The vessel used an automated pressure determining technique to detect the pressure change resulting from the displacement of Helium gas by the tannin samples. Helium was used as the choice gas medium because it is small enough to penetrate virtually all connected pores within a sample. The volume determined was finally divided into sample weights and the microparticle densities of the UMT, EMT ${ }^{\mathrm{P}}$ and EMT $^{S}$ were recorded.

\subsection{In Vitro Release of Tannin from Oil Microcapsules}

The in vitro release properties of the UMT, $\mathrm{EMT}^{\mathrm{P}}$ and $\mathrm{EMT}^{\mathrm{S}}$ were evaluated following the procedure of Adejoro et al. [30] with little change. Three different buffer solutions were prepared: an acetate buffer ( $\mathrm{pH}$ 5.6), citrate buffer $(\mathrm{pH} 2.9)$ and phosphate buffer ( $\mathrm{pH} 7.4)$ simulating the rumen, abomasum, and small intestine $\mathrm{pH}$, respectively $[37,38]$ Samples 
$(100 \mathrm{mg})$ from each of the three mimosa tannin treatments (UMT, EMT ${ }^{\mathrm{P}}$ and $\mathrm{EMT}^{\mathrm{S}}$ ) were separately weighed into $25 \mu \mathrm{m}$ porosity filter bags (F57; ANKOM) and suspended in three separate bottles containing $50 \mathrm{~mL}$ solutions of acetate, citrate and phosphate buffers. The bottles were placed in an incubator shaker and rotated at $50 \mathrm{rpm}$ at $39^{\circ} \mathrm{C}$. The solutions were sampled $(2 \mathrm{~mL})$ in triplicates at intervals as follows: 1, 2, 4, 8, and $24 \mathrm{~h}$ of incubation. The original volume of the media was maintained by the replacement of a $2 \mathrm{~mL}$ fresh buffer immediately after each sampling. The buffer samples collected were frozen immediately for latter analysis. The proportion of mimosa tannins released by the UMT, $\mathrm{EMT}^{\mathrm{P}}$ and $\mathrm{EMT}^{\mathrm{S}}$ into the three different $\mathrm{pH}$ media simulating the GIT at 1, 2, 4, 8, and 24 h were assessed by spectrophotometer absorbance at $725 \mathrm{~nm}$.

The mimosa tannin release kinetics were assessed using the Zero order, First order and Higuchi model (Equations 3-5, respectively) to determine the best model for tannins released by $\mathrm{UMT} \mathrm{EMT}^{\mathrm{P}}$ and $\mathrm{EMT}^{\mathrm{S}}$ microcapsules in the rumen, abomasum and small intestinal simulated buffer as described by Adejoro et al. [30] and Tolve et al. [39]:

$$
\begin{gathered}
\mathrm{Q}_{\mathrm{t}}=\mathrm{Q}_{0}+\mathrm{Q}_{0} \mathrm{t} \\
\log \mathrm{Q}_{\mathrm{t}}=\log \mathrm{Q}_{0}-\mathrm{Q}_{1} \mathrm{t} \\
\mathrm{Q}_{\mathrm{t}}=\mathrm{Q}_{0}-\mathrm{Q}_{\mathrm{H}} \mathrm{t}^{1 / 2}
\end{gathered}
$$

where $\mathrm{k}_{0}=$ Zero-order rate constant; $\mathrm{t}=$ time; $\mathrm{Q}_{\mathrm{t}}=$ released concentration of mimosa tannin at time $\mathrm{t} ; \mathrm{Q}_{0}=$ initial concentration of tannins within solutions (usually $\mathrm{Q}_{0}=0$ ); $\mathrm{k}_{1}=$ First order rate constant and $\mathrm{k}_{\mathrm{H}}=$ Higuchi dissolution constant.

According to Tolve et al. [39], the Zero order kinetic model describes the phenomenon of slow-release, in a shell that does not disintegrate easily and generally applicable to poorly soluble compounds. In First order kinetics, the dissolution of the bioactive compound, which is usually soluble in water and entrapped in a porous shell material, is proportional to its concentration. The Higuchi model refers to release kinetics involving both diffusion and dissolution.

Another experiment was carried out to examine the sequential tannin release at $24 \mathrm{~h}$ in a rumen simulated medium ( $\mathrm{pH}$ 5.6), and at $8 \mathrm{~h}$ each in abomasum ( $\mathrm{pH}$ 2.9) and small intestine ( $\mathrm{pH}$ 7.4) simulated media. The three mimosa tannin treatments (UMT, $\mathrm{EMT}^{\mathrm{P}}$ and $\mathrm{EMT}^{\mathrm{S}}$ ) were weighed $(100 \mathrm{mg})$ in filter bags and suspended in bottles containing acetate buffer $(50 \mathrm{~mL})$. The bottles were placed in shaker incubator and rotated at $50 \mathrm{rpm}$ at $39{ }^{\circ} \mathrm{C}$. The solutions were sampled after $24 \mathrm{~h}$ and the filter bags containing the unencapsulated and encapsulated tannin residues were rinsed with water and subsequently transferred to bottles containing citrate buffer inside incubator shaker set at $50 \mathrm{rpm}$ and $39{ }^{\circ} \mathrm{C}$. The solutions were sampled after $8 \mathrm{~h}$ incubation and the bags containing residue samples were rinsed with water and then suspended in the bottles containing phosphate buffer. The bottles were similarly incubated at $50 \mathrm{rpm}$ and $39^{\circ} \mathrm{C}$ and then sampled after $8 \mathrm{~h}$. Following each incubation period, extracts $(2 \mathrm{~mL})$ were sampled in triplicate and stored inside vials at $-20^{\circ} \mathrm{C}$ before analysis. Three independent incubation cycles was carried out across the three buffer media. The proportion of mimosa tannins released by the UMT, $\mathrm{EMT}^{\mathrm{P}}$ and $\mathrm{EMT}^{\mathrm{S}}$ sequentially after $24 \mathrm{~h}$ of incubation in the respective buffer simulating the rumen, abomasum and small intestine were determined from a spectrophotometer absorbance at $725 \mathrm{~nm}$.

\subsection{Statistical Analysis}

All data were coded in a Microsoft Excel (Microsoft Corp. Redmond, WA, USA) spread sheet and analyzed for variance using SAS version 9.4 (SAS Institute Inc., Carry, NC, USA). Data on encapsulation efficiency and tannin yield, tannin microparticle density and tannin release rate for the $\mathrm{UMT} \mathrm{EMT}^{\mathrm{P}}$ and $\mathrm{EMT}^{\mathrm{S}}$ at various $\mathrm{pH}$ were subjected to one-way ANOVA. Significantly different means were separated using the least significant difference (LSD) and differences reported at $5 \%$ or a $1 \%$ level of probability where applicable. 


\section{Results and Discussion}

\subsection{Characterization of Mimosa Tannins}

Prior to the encapsulation process, mimosa tannin was characterized to ascertain its total phenol, non-tannin phenol, total tannin, condensed tannin and hydrolysable tannin concentrations. The extract comprised of tannin phenol (699.3 $\left.\mathrm{g} \mathrm{kg}^{-1} \mathrm{DM}\right)$, non-tannin phenol (32.3 $\left.\mathrm{g} \mathrm{kg}^{-1} \mathrm{DM}\right)$, total tannin $\left(677.6 \mathrm{~g} \mathrm{~kg}^{-1} \mathrm{DM}\right)$, hydrolysable tannin $\left(463.8 \mathrm{~g} \mathrm{~kg}^{-1}\right.$ $\mathrm{DM})$ and condensed tannin $\left(221.7 \mathrm{~g} \mathrm{~kg}^{-1} \mathrm{DM}\right)$. In corroboration with this finding, several studies reported comparable results $[30,32,40-42]$ for the mimosa tannin characterization.

\subsection{Optimization of Mimosa Tannins' Microcapsules}

The present study did not observe any significant differences between the mimosa tannins encapsulated with palm oil and sunflower oil in terms of tannin yield and encapsulation efficiency. However, a good proportion of tannin yields (59\% vs. 58\%) and encapsulation efficiencies $\left(70 \%\right.$ vs. $68 \%$ ) were obtained from the $\mathrm{EMT}^{\mathrm{P}}$ and $\mathrm{EMT}^{\mathrm{S}}$ microcapsules, respectively. According to Mehran et al. [43], an effective encapsulation technique ensures a high retention of the core materials and only low concentration is trapped on the surface. Moreover, encapsulation efficiency of lipid microcapsules has been shown to depend on the emulsifying properties and viscosity of the coating materials [23,28], as well as the tannin particle size [44] Although, the palm and sunflower microparticles did not differ statistically with regards to their encapsulation efficiency and tannin yield, nevertheless, the slightly higher Ee and yield for the $\mathrm{EMT}^{\mathrm{P}}$ could be attributed to its superior viscosity compared to the EMT ${ }^{\mathrm{S}}$. Davies [45] reported that palm oil had a viscosity of between 20 and $39.5 \mathrm{cP}$ while, sunflower oil had between 17 and $29 \mathrm{cP}$. The higher encapsulation efficiency and tannin yield recorded in the current study compares favorably with the findings of Adejoro et al. [30] who reported tannin yield of $63 \%$ vs. 57\% for acacia tannin encapsulated with palm oil and lard, and Ee of $80 \%$ vs. $69 \%$, respectively. Tolve et al. [39] also obtained a comparable encapsulation efficiency of $76 \%$ in Quebracho condensed tannin encapsulated with gum arabic-maltodextrin using a spray dryer.

Scanning electron microscopy (Figure 1a-c) indicated that $\mathrm{EMT}^{\mathrm{P}}$ and $\mathrm{EMT}^{\mathrm{S}}$ microparticles were smaller and more uniform in size and spherical in shape with a visible whitish oil color enveloping the tannin particles, while UMT morphology revealed tannin particles with bigger and more heterogeneous sizes, irregular shapes and a consistent dark brown colour. This showed that both palm and sunflower oils are good film formers which could be traced to their good emulsifying properties.

With respect to tannin particle density, the results showed that the UMT was heavier $\left(1.44 \mathrm{~g} / \mathrm{cm}^{3}\right)$ than the $\operatorname{EMT}^{\mathrm{S}}\left(1.22 \mathrm{~g} / \mathrm{cm}^{3}\right)$ and the $\operatorname{EMT}^{\mathrm{P}}\left(1.21 \mathrm{~g} / \mathrm{cm}^{3}\right)(p<0.01)$. However, there was no statistical difference between $\mathrm{EMT}^{\mathrm{P}}$ and $\mathrm{EMT}^{\mathrm{S}}$ microcapsules with regards to density. This showed that the unencapsulated mimosa tannin particles, being heavier, might sink to the bottom of the rumen and thus remain longer compared to the palm and sunflower oil microcapsules that, being lighter, could float in the middle of the rumen and hence quickly pass to the next compartment. Kaske and Engelhardt [46] reported that coarser and heavier feed particles had longer retention times in the rumen as well as other compartments.

\subsection{Mimosa Tannin Release Rate Properties}

Numerous studies have revealed the significance of feeding an optimum concentration of mimosa tannins to ruminants to enhance dietary protein utilization, reducing enteric methane production as well as improving the acetate: propionate ratio [12-14,47]. The quality of wall materials is associated with their capacity to preserve the bioactive compound and ensure its delivery to the target site of function [48,49]. Such quality can be assessed by carrying out a release rate trial using a GIT simulated buffer solution [47]. Table 1 presents the summary of in vitro tannin release for the UMT, EMT ${ }^{\mathrm{P}}$ and $\mathrm{EMT}^{\mathrm{S}}$ at predetermine hours in an acetate buffer ( $\mathrm{pH}$ 5.6), citrate buffer ( $\mathrm{pH}$ 2.9) and phosphate buffer $(\mathrm{pH} 7.4)$, simulating the rumen, abomasum, and small intestine, respectively. In the acetate buffer 
(pH 5.6), 68, 77, 81, 90 and 94\% of UMT was released at 1, 2, 4, 8 and $24 \mathrm{~h}$, respectively, and this was significantly higher $(p<0.01)$ compared to the $6.5,10.3,15,19$ and $24 \%$ of tannins released from the EMT ${ }^{S}$ and 5.2, 9.1, 12.3, 16 and $18.3 \%$ released from the $\mathrm{EMT}^{\mathrm{P}}$ at $1,2,4,8$ and $24 \mathrm{~h}$, respectively. There were no statistical effects on the amount of tannin released in a similar medium between the $\mathrm{EMT}^{\mathrm{S}}$ and $\mathrm{EMT}^{\mathrm{P}}$ at 1 and $2 \mathrm{~h}$ of incubation, however, the $\mathrm{EMT}^{\mathrm{S}}$ had a higher tannin release rate from $4-24 \mathrm{~h}$ periods $(p<0.01)$.

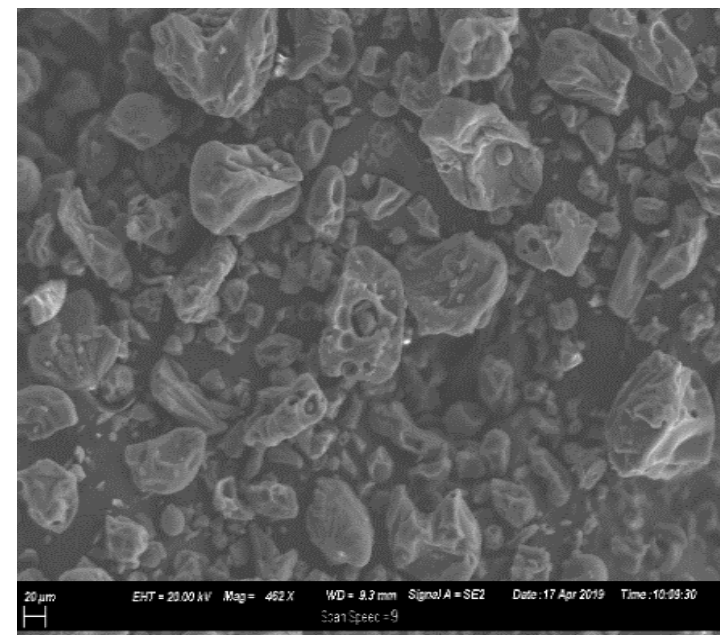

(a)

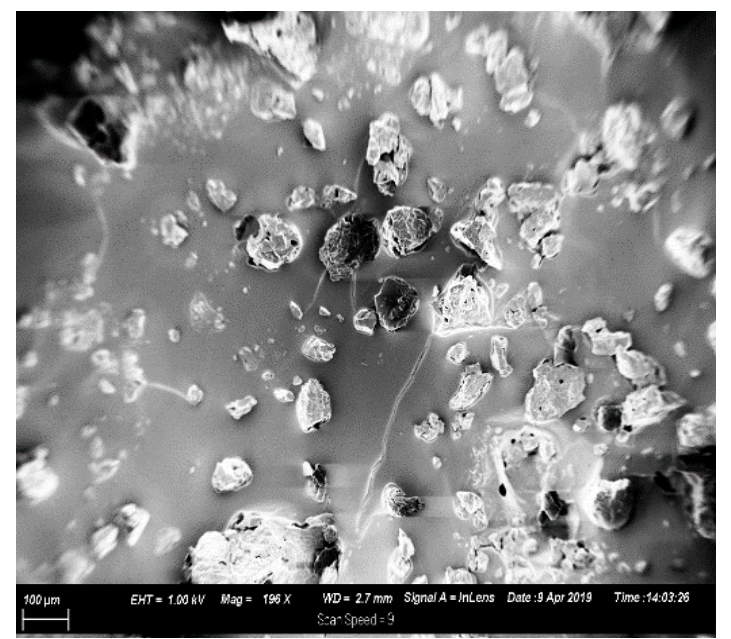

(b)

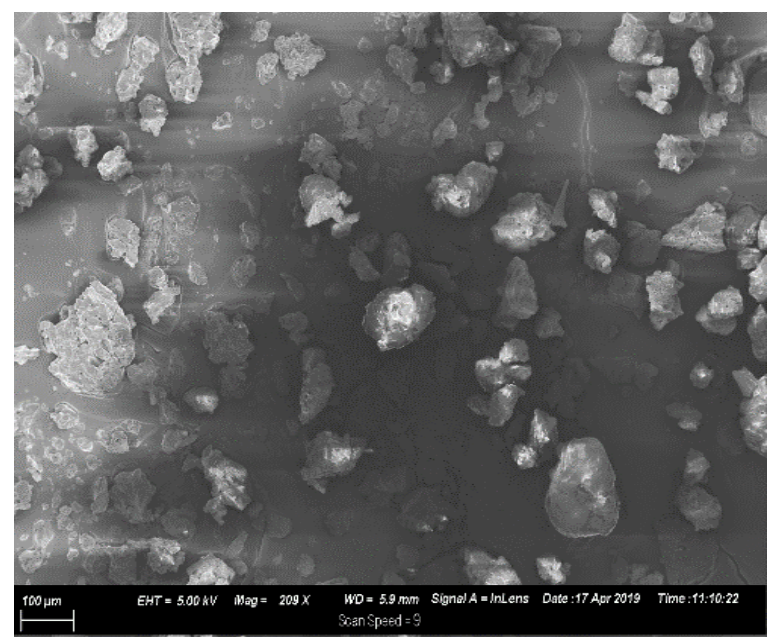

(c)

Figure 1. Morphology of A. mearnsii tannin particles viewed using SEM (a) unencapsulated mimosa tannin, UMT, (b) encapsulated mimosa tannin in palm oil, $\mathrm{EMT}^{\mathrm{P}}$ and (c) encapsulated mimosa tannin in sunflower oil, $\mathrm{EMT}^{\mathrm{S}}$. 
Table 1. In vitro release rate of unencapsulated mimosa tannin or tannins encapsulated with palm and sunflower oils in GIT simulated media.

\begin{tabular}{|c|c|c|c|c|c|c|c|c|c|c|c|c|c|c|c|}
\hline \multirow{2}{*}{$\begin{array}{c}\text { Tannin } \\
\text { Types }\end{array}$} & \multicolumn{5}{|c|}{$\begin{array}{c}\text { Rumen Simulated Buffer } \\
\text { (pH 5.6) }\end{array}$} & \multicolumn{5}{|c|}{$\begin{array}{l}\text { Abomasum Simulated Buffer } \\
\text { (pH 2.9) }\end{array}$} & \multicolumn{5}{|c|}{$\begin{array}{c}\text { Small Intestine Simulated Buffer } \\
\text { (pH 7.4) }\end{array}$} \\
\hline & $1 \mathrm{H}$ & $2 \mathrm{H}$ & $4 \mathrm{H}$ & $8 \mathrm{H}$ & $24 \mathrm{H}$ & $1 \mathrm{H}$ & $2 \mathrm{H}$ & $4 \mathrm{H}$ & $8 \mathrm{H}$ & $24 \mathrm{H}$ & $1 \mathrm{H}$ & $2 \mathrm{H}$ & $4 \mathrm{H}$ & $8 \mathrm{H}$ & $24 \mathrm{H}$ \\
\hline UMT (\%) & $68.0^{a}$ & $76.9^{a}$ & $81.0^{\mathrm{a}}$ & $89.6^{a}$ & $94.1^{\mathrm{a}}$ & $68.5^{\mathrm{a}}$ & $72.8^{a}$ & $79.3^{a}$ & $86.4^{\mathrm{a}}$ & $92.2^{a}$ & $65.8^{a}$ & $71.4^{\mathrm{a}}$ & $80.4^{\mathrm{a}}$ & $87.4^{\mathrm{a}}$ & $95.7^{\mathrm{a}}$ \\
\hline $\mathrm{EMT}^{\mathrm{P}}(\%)$ & $5.19^{b}$ & $9.09^{b}$ & $12.3^{c}$ & $15.6^{c}$ & $18.3^{c}$ & $6.42^{b}$ & $9.70^{\mathrm{b}}$ & $13.4^{\mathrm{b}}$ & $17.0^{\mathrm{b}}$ & $20.4^{\mathrm{b}}$ & $3.57^{\mathrm{b}}$ & $5.71^{\mathrm{c}}$ & $9.34^{b}$ & $11.5^{b}$ & $15.6^{b}$ \\
\hline $\mathrm{EMT}^{\mathrm{S}}(\%)$ & $6.46^{\mathrm{b}}$ & $10.3^{b}$ & $14.8^{\mathrm{b}}$ & $19.0^{\mathrm{b}}$ & $23.7^{b}$ & $6.14^{b}$ & $10.0^{\mathrm{b}}$ & $14.3^{b}$ & $20.0^{\mathrm{b}}$ & $21.4^{\mathrm{b}}$ & $4.47^{b}$ & $6.96^{\mathrm{b}}$ & $10.5^{b}$ & $13.6^{\mathrm{b}}$ & $18.6^{b}$ \\
\hline $\begin{array}{c}\text { SEM } \\
p \text {-value }\end{array}$ & $\begin{array}{c}0.19 \\
<0.01\end{array}$ & $\begin{array}{c}0.39 \\
<0.01\end{array}$ & $\begin{array}{c}0.47 \\
<0.01\end{array}$ & $\begin{array}{l}0.75 \\
<0.01\end{array}$ & $\begin{array}{c}0.93 \\
<0.01\end{array}$ & $\begin{array}{c}0.71 \\
<0.01\end{array}$ & $\begin{array}{c}0.74 \\
<0.01\end{array}$ & $\begin{array}{c}0.92 \\
<0.01\end{array}$ & $\begin{array}{c}0.96 \\
<0.01\end{array}$ & $\begin{array}{c}0.71 \\
<0.01\end{array}$ & $\begin{array}{c}0.49 \\
<0.01\end{array}$ & $\begin{array}{c}0.25 \\
<0.01\end{array}$ & $\begin{array}{c}0.54 \\
<0.01\end{array}$ & $\begin{array}{c}0.54 \\
<0.01\end{array}$ & $\begin{array}{c}0.91 \\
<0.01\end{array}$ \\
\hline
\end{tabular}

Means with different superscripts across the column $(p<0.01)$. TRT $=$ treatment; UMT $=$ unencapsulated mimosa tannin; EMT $^{\mathrm{P}}=$ encapsulated $^{-}$ mimosa tannin in palm oil; $\mathrm{EMT}^{S}=$ encapsulated mimosa tannin in sunflower oil; $\mathrm{SEM}=$ standard error of mean; $\mathrm{H}=$ hour.

In the citrate buffer ( $\mathrm{pH} 2.9$ ), a significantly higher proportion of mimosa tannins $(69,73,79.3,86.4$ and $92.2 \%)$ was released compared to the $6.4,9.7,13.4,17$ and $20.4 \%$ of tannins released from the $\mathrm{EMT}^{\mathrm{P}}$, and 6,10,14, 20 and $21.4 \%$ from $\mathrm{EMT}^{\mathrm{S}}$ microcapsules at 1 , $2,4,8$ and 24 periods, respectively. Nevertheless, no differences in tanninrelease pattern were observed between the EMT ${ }^{\mathrm{S}}$ and $\mathrm{EMT}^{\mathrm{P}}$ at across the time periods $(p>0.05)$. In the phosphate buffer ( $\mathrm{pH} 7.4)$, the UMT released higher proportion of tannins with 66, 71.4, 80.4, 87.4 and $96 \%$ released compared to $4.5,7,11,14$ and $19 \%$ released from the EMT ${ }^{\mathrm{S}}$ microparticles and 4, 6, 9.3, 12 and $16 \%$ released from the EMT ${ }^{\mathrm{P}}$, at 1, 2, 4, 8 and $24 \mathrm{~h}$, respectively $(p<0.01)$. Tannin release rate was significantly different between the EMT ${ }^{S}$ and $\mathrm{EMT}^{\mathrm{P}}$ only at $2 \mathrm{~h}$ of incubation across the acetate, citrate and phosphate buffer media. The significantly higher in vitro release rate of tannin from the UMT compared to those of the EMT ${ }^{\mathrm{S}}$ and $\mathrm{EMT}^{\mathrm{P}}$ across the incubation periods and buffer media could be linked to the entrapment of the tannin within the lipid wall matrices of the microcapsules. In addition, the $\mathrm{EMT}^{\mathrm{S}}$ had a higher release rate than the $\mathrm{EMT}^{\mathrm{P}}$, indicating that the microparticle with a higher Ee released lower tannins and vice versa. This finding is corroborated by the report of Adejoro et al. [30] who obtained a 20\%, 34\% and 25\% tannin release from acacia encapsulated with lard and 19\%,30\% and 22\% from tannin encapsulated with palm oil in acetate, phosphate and $\mathrm{HCl}$ media, respectively, after $24 \mathrm{~h}$ incubation.

The most exciting function of microencapsulation technology has been identified as the provision of sustained release of bioactive compounds to the targeted site at the right time which in turns improves their efficiency and bioavailability $[19,40,50]$. The release profiles of $\mathrm{UMT}^{\mathrm{EMT}}{ }^{\mathrm{P}}$ and $\mathrm{EMT}^{\mathrm{S}}$ in the rumen, abomasum and small intestine simulated buffers are displayed in Figure 2a-c. The chart shows that UMT burst rapidly in the rumen simulated buffer ( $\mathrm{pH} 5.6$ ) with $77 \%$ of the extracts released within $2 \mathrm{~h}$ and about $94 \%$ dissolved after a $24 \mathrm{~h}$ incubation period (Figure 2a). However, the $\mathrm{EMT}^{\mathrm{P}}$ and $\mathrm{EMT}^{\mathrm{S}}$ microcapsules eroded slowly releasing only $9 \%$ and $10 \%$ of the extracts, respectively, in the first $2 \mathrm{~h}$ in the acetate buffer. After $24 \mathrm{~h}, 18 \%$ of the tannins were dissolved from the EMT ${ }^{\mathrm{P}}$ and $24 \%$ from the EMT ${ }^{\mathrm{S}}$. Similarly, in the abomasum simulated buffer ( $\left.\mathrm{pH} 2.9\right)$, about $73 \%$ of the UMT extracts dissolved within $2 \mathrm{~h}$ and $92 \%$ of tannins were released after a $24 \mathrm{~h}$ incubation (Figure $2 \mathrm{~b}$ ). In contrast, only $10 \%$ of the extracts were released by the lipid microcapsules in the first $2 \mathrm{~h}$, while $20 \%$ and $21 \%$ of the extracts were released, respectively, after a $24 \mathrm{~h}$ period. In the small intestine simulated buffer, $71 \%$ of the UMT dissolved in the first $2 \mathrm{~h}$ of incubation (Figure 2c), and after $24 \mathrm{~h}, 96 \%$ of the extracts were released in the buffer. However, only $6 \%$ and $7 \%$ were released by the $\mathrm{EMT}^{\mathrm{P}}$ and $\mathrm{EMT}^{\mathrm{S}}$, respectively, at $2 \mathrm{~h}$. After $24 \mathrm{~h}$, only $16 \%$ of the extracts were dissolved from the $\mathrm{EMT}^{\mathrm{P}}$ and $19 \%$ from the EMT ${ }^{S}$ in the phosphate buffer. In general, the unencapsulated mimosa dissolved faster, releasing most of the extract before $24 \mathrm{~h}$ periods in all the buffers compared to the tannin encapsulated in sunflower oil or palm oil which dissolved slowly releasing the tannin in a sustained manner. This could be attributed to the good emulsifying properties of the palm and sunflower oils. Nevertheless, the sunflower oil microcapsule eroded faster than the palm oil microparticle which could be traced to their variations in viscosity. 


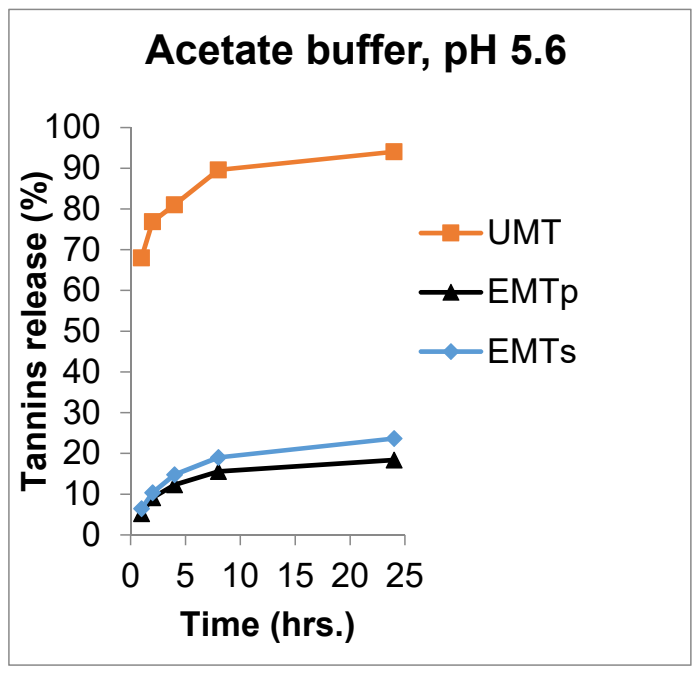

(a)

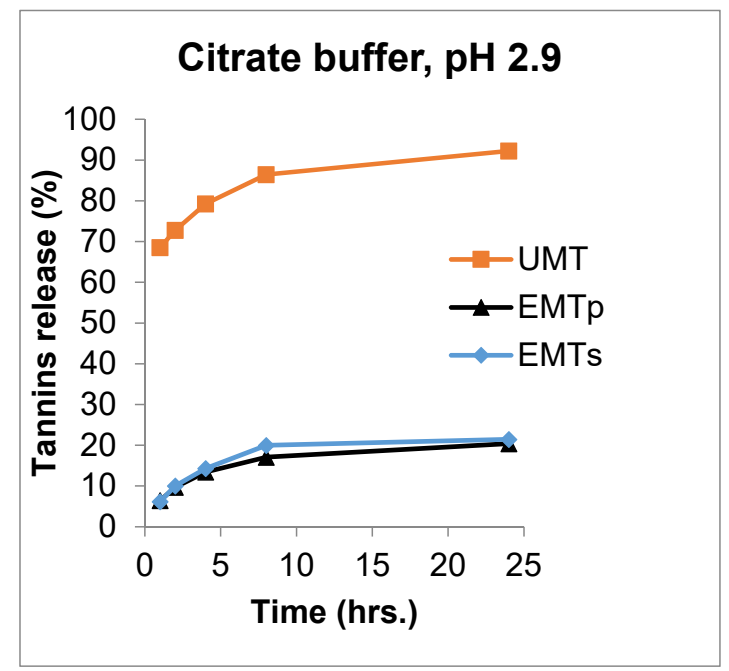

(b)

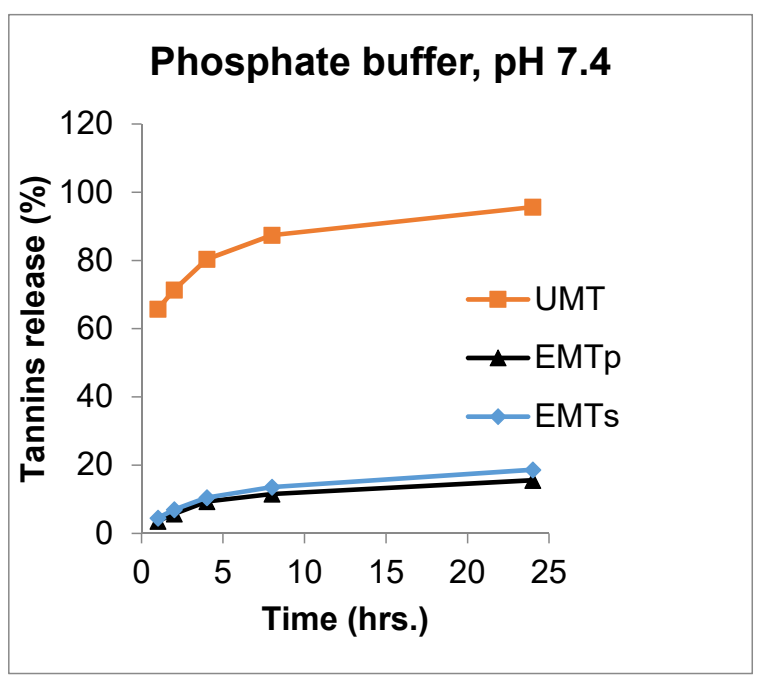

(c)

Figure 2. Release chart for $\mathrm{UMT} \mathrm{EMT}^{\mathrm{P}}$ and $\mathrm{EMT}^{\mathrm{S}}$ in (a) acetate buffer (pH 5.6), (b) citrate buffer ( $\mathrm{pH}$ 2.9) and (c) phosphate buffer ( $\mathrm{pH} 7.4)$.

The tannin release rate kinetics for the $\mathrm{UMT}^{\mathrm{EMT}} \mathrm{EM}^{\mathrm{P}}$ and $\mathrm{EMT}^{\mathrm{S}}$ in the buffers simulating the rumen, abomasum and small intestine are shown in Table 2. The results show that the release pattern for the UMT was best fitted to a negative regression model according to the First order kinetics $\left(\mathrm{R}^{2}=0.87,0.91\right.$ and 0.96$)$, indicated by its immediate burst into the 
various elution media and releasing most of the tannin extract within the first $2 \mathrm{~h}$ of in vitro incubation. However, the $\mathrm{EMT}^{\mathrm{P}}$ and $\mathrm{EMT}^{\mathrm{S}}$ microcapsules did not disintegrate quickly and released smaller proportion of tannins over a $24 \mathrm{~h}$ period in a controlled manner while retaining most of the tannin and thus, the release of tannin fitted with high accuracy to the square root regression equation of the Higuchi order for $\operatorname{EMT}^{\mathrm{P}}\left(\mathrm{R}^{2}=0.86,0.89\right.$ and 0.93$)$ and $\operatorname{EMT}^{S}\left(\mathrm{R}^{2}=0.91,0.81\right.$ and 0.96$)$. This shows that the unidirectional pattern in which mimosa tannins was released into the buffer solutions followed Fick's diffusion law as noted by [48]. Similar patterns were observed by Adejoro et al. [30] and Tolve et al. [39].

Table 2. Release rate kinetics of unencapsulated mimosa tannin or encapsulated mimosa in palm and sunflower oils in GIT simulated media.

\begin{tabular}{|c|c|c|c|c|c|c|c|}
\hline \multirow{4}{*}{$\begin{array}{l}\text { Tannin } \\
\text { UMT }\end{array}$} & \multirow{4}{*}{$\begin{array}{c}\text { Model } \\
\text { Zero } \\
\text { First } \\
\text { Higuchi }\end{array}$} & \multicolumn{2}{|c|}{$\begin{array}{l}\text { Rumen Simulated Buffer } \\
\text { (pH 5.6) }\end{array}$} & \multicolumn{2}{|c|}{$\begin{array}{l}\text { Abomasum Simulated Buffer } \\
(\mathrm{pH} 2.9)\end{array}$} & \multicolumn{2}{|c|}{$\begin{array}{c}\text { Small Intestine Simulated Buffer } \\
(\mathrm{pH} 7.4)\end{array}$} \\
\hline & & $y=0.9125 x+74.781$ & $R^{2}(0.696)$ & $y=0.9033 x+72.801$ & $\mathrm{R}^{2}(0.7752)$ & $\mathrm{y}=1.1231 \mathrm{x}+71.346$ & $\mathrm{R}^{2}(0.7791)$ \\
\hline & & $y=-0.0288 x+1.412$ & $\mathrm{R}^{2}(0.868)$ & $y=-0.0249 x+1.4483$ & $R^{2}(0.9054)$ & $y=-0.0371 x+1.4941$ & $\mathrm{R}^{2}(0.9595)$ \\
\hline & & $y=6.1422 x+66.982$ & $\mathrm{R}^{2}(0.842)$ & $y=5.9738 x+65.34$ & $R^{2}(0.9042)$ & $y=7.4188 x+62.091$ & $\mathrm{R}^{2}(0.9067)$ \\
\hline \multirow{3}{*}{$\mathrm{EMT}^{\mathrm{P}}$} & Zero & $y=0.464 x+8.4782$ & $\mathrm{R}^{2}(0.712)$ & $y=0.5119 x+9.3987$ & $\mathrm{R}^{2}(0.7517)$ & $y=0.4521 x+5.6103$ & $R^{2}(0.8142)$ \\
\hline & First & $y=-0.0023 x+1.9615$ & $\mathrm{R}^{2}(0.730)$ & $y=-0.0033 x+1.9687$ & $R^{2}(0.6809)$ & $y=-0.0026 x+1.9818$ & $\mathrm{R}^{2}(0.7719)$ \\
\hline & Higuchi & $y=3.1161 x+4.5304$ & $\mathrm{R}^{2}(0.857)$ & $y=3.4061 x+5.1203$ & $\mathrm{R}^{2}(0.8877)$ & $y=2.9567 x+1.9571$ & $R^{2}(0.9286)$ \\
\hline \multirow{3}{*}{$\mathrm{EMT}^{\mathrm{S}}$} & Zero & $y=0.6368 x+9.8738$ & $\mathrm{R}^{2}(0.779)$ & $y=0.5522 x+10.07$ & $R^{2}(0.648)$ & $y=0.5424 x+6.5923$ & $\mathrm{R}^{2}(0.8496)$ \\
\hline & First & $y=-0.0033 x+1.955$ & $R^{2}(0.802)$ & $y=-0.0036 x+1.9662$ & $\mathrm{R}^{2}(0.6318)$ & $y=-0.0032 x+1.9785$ & $\mathrm{R}^{2}(0.7983)$ \\
\hline & Higuchi & $y=4.2071 x+4.6243$ & $\mathrm{R}^{2}(0.907)$ & $y=3.7714 x+5.2192$ & $\mathrm{R}^{2}(0.8063)$ & $y=3.5169 x+2.283$ & $\mathrm{R}^{2}(0.9526)$ \\
\hline
\end{tabular}

Figure 3 presents the sequential release of tannin extract from the UMT, EMT ${ }^{\mathrm{P}}$ and $\mathrm{EMT}^{\mathrm{S}}$ microcapsules. In the acetate buffer, $90.4 \%$ of UMT extracts dissolved after $24 \mathrm{~h}$, while in the citrate buffer $5.1 \%$ was released within $8 \mathrm{~h}$ but nothing was recorded in the phosphate buffer after an $8 \mathrm{~h}$ sequential incubation. In contrast, the EMT ${ }^{\mathrm{S}}$ and $\mathrm{EMT}^{\mathrm{P}}$ matrixes released $30 \%$ and $22 \%$ tannins, respectively, in the acetate buffer over the period of $24 \mathrm{~h}$, and $10 \%$ each in the citrate buffer within $8 \mathrm{~h}$, while in the phosphate buffer, the $\mathrm{EMT}^{\mathrm{P}}$ released $6 \%$ extract and $\mathrm{EMT}^{\mathrm{S}} 7 \%$ after an $8 \mathrm{~h}$ incubation. Generally, most of the extracts from the UMT were dissolved in the rumen simulated buffer and a small proportion (5\%) released in the abomasum simulated buffer, while no tannin was detected in the buffer simulating the small intestine. However, for the $\mathrm{EMT}^{\mathrm{S}}$ and $\mathrm{EMT}^{\mathrm{P}}$, less than one third of the extracts were released in the buffer simulating the rumen after $24 \mathrm{~h}$ and an appreciable amount were dissolved in the abomasum and small intestine simulated media. This further confirmed the emulsifying properties of the lipid microcapsules which reduced the tannin release in the media. Literature on sequential tannin release is scarce, thus it is difficult to compare these findings with previous reports.

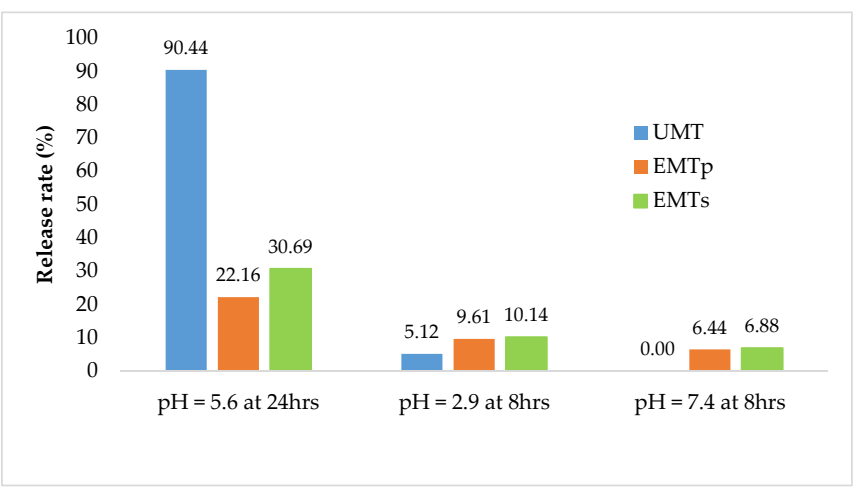

Figure 3. Sequential release rate for $\mathrm{UMT}^{\mathrm{EMT}} \mathrm{EM}^{\mathrm{S}}$ and $\mathrm{EMT}^{\mathrm{P}}$ in acetate, citrate and phosphate buffers.

\section{Conclusions}

The current investigation showed that palm oil and sunflower oil could be adopted as coating materials in encapsulating Mimosa tannin to mask the tannin's bitter taste and 
control the release of the extract in the GIT. The encapsulated mimosa tannins demonstrated good encapsulation efficiencies, had smaller particle sizes and were lighter than the unencapsulated tannin. Palm or sunflower oil microcapsules also stabilized the tannins' release in gastrointestinal tract simulated buffers at predetermined periods with the potential to modify rumen fermentation. Further studies should be conducted on the lipid stability of microparticles, fatty acids transfer rate and the antioxidant properties of encapsulated tannins to justify commercial application.

Author Contributions: Conceptualization, S.L.I. and A.H.; data collection and analysis, S.L.I.; supervision, A.H.; original draft manuscript, S.L.I.; review and editing, S.L.I. and A.H.; funding acquisition, A.H. All authors have read and agreed to the published version of the manuscript.

Funding: Running cost of the research was funded by the National Research Foundation, South Africa under grant No 118518, and the University of Pretoria awarded a PhD research bursary to the first author.

Institutional Review Board Statement: This research was approved by the Animal Ethics Committee of the University of Pretoria (Ref No: EC075-17).

Acknowledgments: The authors wish to express gratitude to the University of Pretoria Microscopy and Microanalysis laboratory for the scanning electron microscopy, and the Civil Engineering laboratory for particle density analysis. The authors also thank the National Research Foundation, South Africa for funding the research under grant No 118518, and the University of Pretoria for a PhD research bursary award to the first author.

Conflicts of Interest: The authors declare no conflict of interest in this investigation.

\section{References}

1. Patra, A.K.; Kamra, D.N.; Agarwal, N. Effect of plant extracts on in vitro methanogenesis, enzyme activities and fermentation of feed in rumen liquor of buffalo. Anim. Feed. Sci. Technol. 2006, 128, 276-291. [CrossRef]

2. Piñeiro-Vázqueza, A.T.; Canul-Solísa, J.R.; Alayón-Gamboab, J.A.; Chay-Canulc, A.J.; Ayala-Burgosa, A.J. Potential of condensed tannins for the reduction of emissions of enteric methane and their effect on ruminant productivity Potencial de los taninos condensados para reducir las emisiones de metano entérico y sus efectos en producción de ruminates. Arch. Med. Vet. 2015, 47, 263-272. [CrossRef]

3. Animut, G.; Puchala, R.; Goetsch, A.L.; Patra, A.K.; Sahlu, T.; Varel, V.H.; Wells, J. Methane emission by goats consuming diets with different levels of condensed tannins from lespedeza. Anim. Feed Sci. Technol. 2008, 144, 212-227. [CrossRef]

4. Goel, G.; Makkar, H.P.S.; Becker, K. Effects of Sesbania sesban and Carduus pycnocephalus leaves and Fenugreek (Trigonella foenum-graecum L.) seeds and their extracts on partitioning of nutrients from roughage- and concentrate-based feeds to methane. Anim. Feed Sci. Technol. 2008, 147, 72-89. [CrossRef]

5. Hristov, A.N.; Oh, J.; Firkins, J.L.; Dijkstra, J.; Kebreab, E.; Waghorn, G.; Makkar, H.P.S.; Adesogan, A.T.; Yang, W.; Lee, C.; et al. Special topics-Mitigation of methane and nitrous oxide emissions from animal operations: I. A review of enteric methane mitigation options. J. Anim. Sci. 2013, 19, 5045-5069. [CrossRef]

6. Hassanpour, S.; Sadaghian, M.; MaheriSis, N.; Eshratkhah, B.; ChaichiSemsari, M. Effect of condensed tannin on controlling faecal protein excretion in nematode-infected sheep. J. Am. Sci. 2011, 7, 896-900.

7. Hassanpour, S.; Mehmandar, F.B. Anthelmintic effects of Acacia mearnsii (Wattle tannin) in small ruminants; A review. J. Comp. Clin. Pathol. Res. 2012, 1, 1-8.

8. Vasta, V.; Nudda, A.; Cannas, A.; Lanza, M.; Priolo, A. Alternative feed resources and their effects on the quality of meat and milk from small ruminants. Anim. Feed Sci. Technol. 2008, 147, 223-246. [CrossRef]

9. Kardel, M.; Taube, F.; Schulz, H.; Schütze, W.; Gierus, M. Different approaches to evaluate tannin content and structure of selected plant extracts-review and new aspects. J. Appl. Bot. Food Qual. 2013, 166, 154-166. [CrossRef]

10. Galatowitsch, S.; Richardson, D.M. Riparian scrub recovery after clearing of invasive alien trees in headwater streams of the Western Cape, South Africa. Biol. Conserv. 2005, 122, 509-521. [CrossRef]

11. de Wit, M.P.; Crookes, D.J.; Van Wilgen, B.W. Conflicts of interest in environmental management: Estimating. Biol. Invasions 2001, 3, 167-178. [CrossRef]

12. Grainger, C.; Clarke, T.; Auldist, M.J.; Beauchemin, K.A.; McGinn, S.M.; Waghorn, G.C.; Eckard, R.J. Potential use of Acacia mearnsii condensed tannins to reduce methane emissions and nitrogen excretion from grazing dairy cows. Can. J. Anim. Sci. 2009, 89, 241-251. [CrossRef]

13. Carulla, J.E.; Kreuzer, M.; Machmüller, A.; Hess, H.D. Supplementation of Acacia mearnsii tannins decreases methanogenesis and urinary nitrogen in forage-fed sheep. Aust. J. Agric. Res. 2005, 56, 951-969. [CrossRef] 
14. Hassanat, F.; Benchaar, C. Assessment of the effect of condensed (acacia and quebracho) and hydrolysable (chestnut and valonea) tannins on rumen fermentation and methane production in vitro. J. Sci. Food Agric. 2013, 93, 332-339. [CrossRef] [PubMed]

15. Frutos, P.; Hervás, G.; Giráldez, F.J.; Mantecón, A.R. Review. Tannins and ruminant nutrition. Spanish J. Agric. Res. 2004, 2, 191-202. [CrossRef]

16. Dschaak, C.M.; Williams, C.M.; Holt, M.S.; Eun, J.S.; Young, A.J.; Min, B.R. Effects of supplementing condensed tannin extract on intake, digestion, ruminal fermentation, and milk production of lactating dairy cows. J. Dairy Sci. 2011, 94, 2508-2519. [CrossRef]

17. Min, B.R.; Barry, T.N.; Attwood, G.T.; McNabb, W.C. The effect of condensed tannins on the nutrition and health of ruminants fed fresh temperate forages: A review. Anim. Feed Sci. Technol. 2003, 106, 3-19. [CrossRef]

18. Beauchemin, K.A.; Kreuzer, M.; O’Mara, F.; McAllister, T.A. Nutritional management for enteric methane abatement: A review. Aust. J. Exp. Agric. 2008, 48, 21. [CrossRef]

19. Priolo, A.; Waghorn, G.C.; Lanza, M.; Biondi, L.; Pennisi, P. Polyethylene glycol as a means for reducing the impact of condensed tannins in carob pulp: Effects on lamb growth performance and meat quality. J. Anim. Sci. 2000, 78, 810-816. [CrossRef]

20. Bhatta, R.; Enishi, O.; Yabumoto, Y.; Nonaka, I.; Takusari, N.; Higuchi, K.; Tajima, K.; Takenaka, A.; Kurihara, M. Methane reduction and energy partitioning in goats fed two concentrations of tannin from Mimosa spp. J. Agric. Sci. 2013, 151, 119-128. [CrossRef]

21. Fang, Z.; Bhandari, B. Encapsulation of polyphenols-A review. Trends Food Sci. Technol. 2010, 21, 510-523. [CrossRef]

22. Munin, A.; Edwards-Lévy, F. Encapsulation of Natural Polyphenolic Compounds; a Review. Pharmaceutics 2011, 3, 793-829. [CrossRef]

23. Bakry, A.M.; Abbas, S.; Ali, B.; Majeed, H.; Abouelwafa, M.Y.; Mousa, A.; Liang, L. Microencapsulation of Oils: A Comprehensive Review of Benefits, Techniques, and Applications. Compr. Rev. Food Sci. Food Saf. 2016, 15, 143-182. [CrossRef]

24. Gharsallaoui, A.; Roudaut, G.; Chambin, O.; Voilley, A.; Saurel, R. Applications of spray-drying in microencapsulation of food ingredients: An overview. Food Res. Int. 2007, 40, 1107-1121. [CrossRef]

25. Jafari, S.M.; Assadpoor, E.; He, Y.; Bhandari, B. Encapsulation Efficiency of Food Flavours and Oils during Spray Drying. Drying Technol. 2008, 26, 816-835. [CrossRef]

26. Abedi, A.; Rismanchi, M.; Shahdoostkhany, M.; Mohammadi, A.; Hosseini, H. Microencapsulation of Nigella sativa seeds oil containing thymoquinone by spray-drying for functional yogurt production. Int. J. Food Sci. Technol. 2016, 51, 2280-2289. [CrossRef]

27. Krishnan, S.; Bhosale, R.; Singhal, R.S. Microencapsulation of cardamom oleoresin: Evaluation of blends of gum arabic, maltodextrin and a modified starch as wall materials. Carbohydrate Poly. 2005, 61, 95-102. [CrossRef]

28. Flanagan, J.; Singh, H. Microemulsions: A Potential Delivery System for Bioactives in Food. Critical Rev. Food Sci. Nutr. 2006, 46, 221-237. [CrossRef]

29. Eckard, R.J.; Grainger, C.; de Klein, C.A.M. Options for the abatement of methane and nitrous oxide from ruminant production: A review. Livest. Sci. 2010, 130, 47-56. [CrossRef]

30. Adejoro, F.A.; Hassen, A.; Thantsha, M.S. Preparation of acacia tannin loaded lipid microparticles by solid-in-oil-in-water and melt dispersion methods, their characterization and evaluation of their effect on ruminal gas production In Vitro. PLoS ONE 2018, 13, e0206241. [CrossRef]

31. van Niekerk, W.A.; Hassen, A.; Snyman, L.D.; Rethman, N.F.G.; Coertze, R.J. Influence of mineral composition and rumen degradability of Atriplex nummularia (Hatfield Select F1) plants on selection preference of sheep. Afr. J. Range Forage Sci. 2009, 26, 91-96. [CrossRef]

32. Missio, A.L.; Tischer, B.; dos Santos, P.S.B.; Codevilla, C.; de Menezes, C.R.; Barin, J.S.; Haselein, C.R.; Labidi, J.; Gatto, D.A.; Petutschnigg, A.; et al. Analytical characterization of purified mimosa (Acacia mearnsii) industrial tannin extract: Single and sequential fractionation. Sep. Purif. Technol. 2017, 186, 218-225. [CrossRef]

33. Makkar, H.P.S. A laboratory manual for the FAO/IAEA co-ordinated research project on 'Use of nuclear and related technique to develop simple tannin assays for predicting and improving the safety and efficiency of feeding ruminants on tanniferous tree foliage'. In Quantification of Tannins in Tree and Shrub Foliage; Joint FAO/IAEA Division of Nuclear Techniques in Food and and Agriculture; IAEA: Vienna, Austria, 2000; 31p.

34. Porter, L.N.; Hrstich, L.J.; Chans, B.G. The conversion of procyanidins and prodelphinidins to cyanidin and delphinidin. Phytochemistry 1986, 2, 223-230. [CrossRef]

35. Singh, B.; Sahoo, A.; Sharma, R.; Bhat, T.K. Effect of polethylene glycol on gas production parameters and nitrogen disappearance of some tree forages. Anim. Feed Sci. Technol. 2005, 123, 351-364. [CrossRef]

36. Taylor, J.; Taylor, J.N.R.; Belton, P.S.; Minnaar, A. Kafirin Microparticle Encapsulation of Catechin and Sorghum Condensed Tannins. J. Agric. Food Chem. 2009, 57, 7523-7528. [CrossRef]

37. Papas, A.M.; Sniffen, C.J.; Muscato, T.V. Effectiveness of Rumen-Protected Methionine for Delivering Methionine Postruminally in Dairy Cows. J. Dairy Sci. 1984, 67, 545-552. [CrossRef]

38. Rossi, F.; Maurizio, M.; Francesco, M.; Giovanna, C.; Gianfranco, P. Rumen degradation and intestinal digestibility of rumen protected amino acids: Comparison between in situ and in vitro data. Anim. Feed Sci. Technol. 2003, 108, 223-229. [CrossRef]

39. Tolve, R.; Galgano, F.; Condelli, N.; Cela, N.; Lucini, L.; Caruso, M.C. Optimization model of phenolics encapsulation conditions for biofortification in fatty acids of animal food products. Foods 2021, 10, 881. [CrossRef] [PubMed] 
40. Adejoro, F.A.; Hassen, A.; Thantsha, M.S. Characterization of starch and gum Arabic-maltodextrin microparticles encapsulating Acacia tannin extract and evaluation of their potential use in ruminant nutrition. Asian-Australas J. Anim. Sci. 2019, 32, 977-987. [CrossRef]

41. Kozloski, G.V.; Härter, C.J.; Hentz, F.; de ávila, S.C.; Orlandi, T.; Stefanello, C.M. Intake, digestibility and nutrients supply to wethers fed ryegrass and intraruminally infused with levels of Acacia mearnsii tannin extract. Small Rumin. Res. 2012, 106, 125-130. [CrossRef]

42. Bhatta, R.; Uyeno, Y.; Tajima, K.; Takenaka, A.; Yabumoto, Y.; Nonaka, I.; Kurihara, M. Difference in the nature of tannins on in vitro ruminal methane and volatile fatty acid production and on methanogenic archaea and protozoal populations. J. Dairy Sci. 2009, 92, 5512-5522. [CrossRef]

43. Mehran, M.; Masoum, M.; Memarzadeh, S. Microencapsulation of Mentha spicata essential oil by spray drying: Optimization, characterization, release kinetics of essential oil from microcapsules in food models. Ind. Crop. Prod. 2020, 154, 112694. [CrossRef]

44. Castellanos, I.J.; Carrasquillo, K.G.; López, J.D.J.; Alvarez, M.; Griebenow, K. Encapsulation of bovine serum albumin in poly(lactide-co-glycolide) microspheres by the solid-in-oil-in-water technique. J. Pharm. Pharmacol. 2001, 53, 167-178. [CrossRef] [PubMed]

45. Davies, R. Effect of the temperature on dynamic viscosity, density and flow rate of some vegetable oils. J. Sci. Res. Engr. Technol. 2016, 1, 14-24.

46. Kaske, M.; Engelhardt, W.V. The effect of size and density on mean retention time of particles in the gastrointestinal tract of sheep. Br. J. Nutr. 1990, 63, 457-465. [CrossRef]

47. Adejoro, F.A.; Hassen, A.; Akanmu, A.M.; Morgavi, D.P. Replacing urea with nitrate as a non-protein nitrogen source increases lamb growth and reduces methane production, whereas mimosa tannin has no effect. Anim. Feed Sci. Technol. 2019, 259, 114360. [CrossRef]

48. Martínez, M.R.S.; Ruiz, J.P.Q.; Campos, J.C.R. Release kinetic studies of Stevia rebaudiana extract capsules from sodium alginate and inulin by ionotropic gelation. Adv. Mater. Sci. Eng. 2018, 2018, 6354924.

49. Kar, S.; Kundu, S.; Reis, B.; Sarkar, R.L.; Nandy, R.; Basu, P.; Das, R. Curcumin ameliorates the targeted delivery of methotrexate Sci. intercalated montmorillonite clay to cancer cells. Eur. J. Pharm. 2019, 135, 91-102. [CrossRef]

50. Augustin, B.J.F.A.; Sanguansri, M.A.; Margetts, L.; Young, C. Microencapsulating food ingredients. Food Aust. 2001, 53, $220-223$. 